\title{
Media Valuations of Health Journalism and Health Dynamics in Brazilian Printed Media
}

\author{
Tatiana Breder Emerich ${ }^{1}$, Aline Guio Cavaca ${ }^{1}$, Edson Theodoro Santos-Neto ${ }^{1}$, Victor Israel Gentilli ${ }^{2}$, Adauto Emmerich \\ Oliveira $^{1}$ \\ ${ }^{1}$ Post-Graduate Program in Collective Health, Federal University of Espirito Santo, Brazil \\ ${ }^{2}$ Post-Graduate Program in Communication and Territoriality, Federal University of Espirito Santo, Brazil \\ Correspondence: Tatiana Breder Emerich, Post-Graduate Program in Collective Health, Federal University of Espirito \\ Santo, Brazil.
}

Received: November 21, 2016

Accepted: December 6, 2016

Available online: December 20, 2016

doi:10.11114/ijsss.v5i1.1997

URL: http://dx.doi.org/10.11114/ijsss.v5i1.1997

\begin{abstract}
The objective of this study was to understand the opinions of journalists and health managers regarding the dynamics of health news dissemination in printed newspapers from the state of Espírito Santo, Brazil. Semi-structured interviews were conducted with three journalists from the A Tribuna newspaper, three journalists from the A Gazeta newspaper, two editors from these newspapers, two press officers from the Department of Health of Espírito Santo, Brazil and five health managers. The interviews were analysed using content analysis, with Social Representation Theory as a reference. The data analysis revealed that the newspapers tend to value the negative, the quantitative, the novel, and the aesthetic. Similarly, evidence was found for the factors that determine which health issues/diseases will be addressed by the printed media. The respondents' answers also emphasised the main difficulties of health journalism, which mainly concern journalists' relationship with their sources. It was concluded that harmony between these actors is rare, which can lead to a decrease in the quality of health news.
\end{abstract}

Keywords: health communication, public health, mass communication, qualitative study, health journalism

\section{Introduction}

\subsection{Introduce the Problem}

The world stage is marked by the influence of the mass media in various sectors of society. The media is society's main source of information about public policy. For this reason, the media tends to shape public opinion both generally and in the domain of public health policies (Collins, Abelson, Pyman, Lavis, 2006; O’Connor \& Jeffe, 2013; Hilton, Wood, Patterson, Katikire, \& Nikora, 2014).

The prominent field of Communication and Health emerged in Brazil in the mid-1990s. It includes knowledge from the fields of Communication and Public Health and thus includes the debate over the representation of health news in the mass media (Araújo \& Cardoso, 2007).

The actors involved in the mediatisation (Fausto Neto, 2012) of health- or disease-related topics include several professionals, managers, and figures who publicise the different topics and approaches (Romeyer, 2010; Hilton, Wood, Patterson, Katikire, \& Nikora, 2014). Therefore, understanding the opinions of these key actors involved in the propagation of health news becomes an important object of study.

\subsection{Explore Importance of the Problem}

Daily printed newspapers share what is important and/or interesting to life and to the world through news (Traquina, 2004). With regard to health, newspapers include news on diseases, life stories, deaths, births (Traquina, 2004; Romeyer, 2010), health systems and policies, (Oliveira, 2000; Collins, Abelson, Pyman, Lavis, 2006; Menegon, 2008; Ortona \& Fortes, 2012; Hilton, Wood, Patterson, Katikire, \& Nikora, 2014), aesthetics (Cavaca, Gentilli, Zandonade, Cortellete Junior, \& Emmerich, 2012; Oliveira, 2013), and prevention (Castiel \& Vasconcellos-Silva, 2006; O’Connor \& Joffe, 2013), among other topics.

The definition of news is neither a closed, static concept nor a scientific concept (Traquina, 2013). It exists when there 
is a break in the normal state of events and facts, guided by criteria, which are called news values or newsworthiness criteria, which make it deserving of notice (Traquina, 2013).

The effects generated by news include its role as a source of information; its thematic schedule capacity, which increases the importance of new or existing issues; the ways of framing/presenting news; and its power of persuasion, i.e., "who says what to whom” (Collins, Abelson, Pyman, Lavis, 2006).

The term health news as used in this study includes all information disclosed by newspapers covering the topic of health in its dimension of absence of disease and in the perspective of complete physical, mental, and social well-being agreed upon by the World Health Organization (WHO).

\subsection{Describe Relevant Scholarship}

Understanding the opinions of journalists and their sources with regard to health news is important because this subject has not yet been discussed extensively. This understanding is also relevant because it helps detect neglected themes and promote higher-quality health news coverage (Marinho, Ruão, Lopes, Pinto-Coelho, \& Fernandes, 2012).

\subsection{State Hypotheses and Their Correspondence to Research Design}

In this study, opinion is assumed as an imprecise category that exists in the representation of what one talks about (Herzlich \& Pierret, 2005).

From this perspective, the aim of this study is to understand the opinions of journalists and health managers regarding the dynamics of health news dissemination in printed media in the state of Espírito Santo, Brazil.

\section{Method}

A qualitative study followed by the guide for qualitative research COREQ (Tong, Sainsbury \& Craig, 2007) was conducted using the technique of face-to-face individual interview, with the support of a previously prepared, semi-structured script. The semi-structured interview technique was chosen because the objective was to comprehend, in depth, the opinions of the respondents on the subject (Minayo, 2010).

The interview script included elements to help understand these professionals' views regarding the dynamics of the dissemination of health- and disease-related news, in addition to the assumptions that underlie the choice of health topics to be covered and the relationship between journalists and their sources.

\subsection{Location of the Study}

The state of Espírito Santo, Brazil, was chosen as the study setting. The state has a population of approximately 4,000,000 people who live an area of 46,096 $\mathrm{km}^{2}$. It has 78 municipalities, and its capital is the city of Vitória, where the newspapers A Tribuna and A Gazeta stand out. The newspaper A Gazeta is the oldest periodical still in circulation in the state (Jornal A Gazeta, 2015), and A Tribuna is currently the leader in circulation (Jornal A Tribuna, 2015).

Since 2004, the Department of Health of Espírito Santo (Secretaria Estadual de Saúde do Estado do Espírito Santo SESA) has received communication support from the Social Communication Advisory (Assessoria de Comunicação Social - ASSCOM). The advisory is designed to assist the administrative units of the SESA in matters of social communication. Its functions include the relationship with the press, in addition to other actions that allow full access to health information and social mobilisation (Brasil, 2004). Currently, the advisory has been the link between journalists and health managers in Espírito Santo.

\subsection{Participant Selection Criteria}

Because these are news that address health and diseases, the guided sampling technique was used. The technique involves selecting respondents based on their ability to meet the proposed objectives (Tong, Sainsbury \& Craig, 2007). Therefore, key actors involved in shaping the news about health and disease were interviewed.

Journalists were selected by prior research in both newspapers to identify which reporters were responsible for producing news about health and diseases. In addition, the sections in which the topic of health and disease was more common were identified; thus, the editors-in-chief of these sections were also interviewed.

The snowball technique, by which the first participant indicates the second participant to be included in the study and so forth, was used to select health managers (Tong, Sainsbury \& Craig, 2007). The first interviewee was a manager at the SESA Science and Technology Centre who indicated the other actors. In the case of the SESA ASSCOM, the communication advisors who had agreed to participate in the study were interviewed.

Following the saturation criterion proposed by Minayo (2010), the total final sample was composed of 15 respondents: three journalists from the newspaper A Tribuna; three journalists from the newspaper A Gazeta; two editors (one from A Tribuna and one from A Gazeta); two journalists of the SESA ASSCOM; five health managers with the National Public 
Health System (Sistema Único de Saúde - SUS) (one from the area of Planning, one from Health Surveillance, one from Epidemiological Surveillance and two managers who served as technical references).

\subsection{Ethical Considerations}

The study was approved by the Research Ethics Committee of the Federal University of Espírito Santo (Universidade Federal do Espírito Santo - UFES), Brazil, on May, 28, 2014 (CAAE 2589313.0.0000.5060). All of the respondents agreed to participate in the study by signing an informed consent form.

\subsection{Interview Setting}

The participants could choose their preferred location for the interview: in their own workplace or in a room on campus at UFES. The interviews were conducted by the graduate student responsible for the study from July to October 2014, and they had an average duration of 30 minutes. The interviews were recorded, transcribed, and sent to the respondents by e-mail.

\subsection{Analysis of the Interviews}

The technique for interpretative analysis of thematic content recommended by Bardin (2011) was used, following the three basic steps detailed in Figure 1.

\section{Figure 1}

SADQ MAXqda 11.0 qualitative data analysis software was used as a tool for categorisation. This software makes qualitative analysis more accurate, reliable, and transparent without interfering in the reading, categorisation, and reflection stages, which are still performed by the researcher (Gibbs, 2009).

The material was studied based on the theoretical framework of Social Representation Theory. This theory considers that the set of ideas that express a person's opinion is socially conditioned and constructed based on the context in which he or she is inserted and his or her standards and practices (Moscovici, 2009; Spink, 1993). This theory seeks to unveil the web of meanings that sustains everyday life and society, including dynamism, cultural multiplicity, diversities, and contradictions. It encompasses the construction of knowledge and the functionality of this knowledge in the establishment or maintenance of social practices (Spink, 1993).

It is believed that based on this theory, it is possible to respond to the inquiries and to know the influence of the various contexts in which each group of actors is inserted and how these contexts (social and professional) can influence the answers and the object of study in question.

\section{Results and Discussion}

After reading the material and selecting the fragments to be examined, 12 categories emerged from the body of interviews, which were grouped into three dimensions, detailed in Frame 1.

\section{Frame 1}

A discussion of the three dimensions is inseparable from the social context of the work ethos and the aims of the journalists (Traquina, 2004), press advisors (Martinuzzo, 2013; Caldas, 2003), and health managers (Rodriguez, Berenguera, Pujol-Ribera, Capella, Luiz de Peray, Roma, 2013; André \& Cimapone, 2007), which directly influences the representation of the opinions about the valuations, demands, and difficulties that pervade health news. By sharing an ethos inherent to each professional practice, journalists, press advisors, and managers perceive the dissemination dynamics of health news through their own glasses, whose lenses are permeated by values and by a set of professional norms peculiar to each role (Traquina, 2013).

\subsection{Media Valuations}

The first analytical dimension reflects the concepts inherent to the newsworthiness criteria of journalism, that is, news values. They refer to the attributes that the mass media identifies as those that make events deserve to be known by the public (Silva, 2014). According to Traquina (2013), news values are the glasses that make journalists see certain things but not see others and determine the manner in which journalists see them. Traquina divides them into the following: selection news values (notoriety, proximity, novelty, time, notability, unexpectedness, infraction, scandal, availability, balance, visuality, competition and news day); and construction news values (simplification, amplification, relevance, personification, dramatisation, and consonance) (Traquina, 2013).

These values are changeable according to the historical moment and are sensitive to variations between localities (Traquina, 2013). They are part of the productive routine of journalists, their professional culture, and how the news is produced. Therefore, the information conveyed by these actors tends to value what they consider relevant to the audience being addressed (Martinuzzo, 2013). 
The answers of the respondents indicated that newspapers prioritise health news with a negative slant or, as defined by other authors, bad news (Barlett, Sterne, Egger, 2002) or news of a pessimistic character (Carlini, 2012). In this sense, news that highlights the problems of the Brazilian health system (Oliveira, 2000), diseases considered the most severe, and those that kill the most predominate (Tabakman, 2013; Cavaca \& Vasconcellos-Silva, 2015; Cavaca, Emerich, Vasconcellos-Silva, dos Santos-Neto, Oliveira, 2016):

“[...] what is important in diseases? What kills, you know? Or anything that is new” (Press Advisor).

"[...] it is very hard for the area of Public Health to get praise from the press" (Press Advisor).

These approaches often end up weakening the SUS politically and ideologically (Oliveira, 2000).

However, although SESA management understands that newspapers are businesses with their own production routines, managers and journalists from ASSCOM suggest that there should be a counterpart to this negativity in health news, which seems to us to be a type of blackmail by the newspapers against the government:

"Yes, it is a private company, but in addition to choosing chaotic news, which takes a whole page to talk about someone who has not cared for something, the other side could be reported" (Manager).

The question raised by the manager and by the ASSCOM accords with the assertion of Friedman, Tanner \& Rose (2014) that the current state of health journalism "is good but could be better". Nevertheless, "improving" newsworthiness involves premises that go beyond media valuations and include the potential audience for the news, in addition to the relationship between journalists and their sources (Friedman, Tanner, Rose 2014).

The participants also stressed that health news, especially those related to diseases, focus on diseases that kill or affect the greatest number of individuals. This criterion emphasises how health news have been placed on the agenda in the media with a quantitative bias, and in that respect, there are relevant issues that are rarely reported (Romeyer, 2010; Cavaca \& Vasconcellos-Silva, 2015; Emerich, Vasconcellos-Silva, dos Santos-Neto, Oliveira, 2016). Thus, epidemics or chronic diseases tend to be publicised to the detriment of rare diseases and those that affect minorities (Tabakman, 2013).

One of the journalists clearly explains this logic:

“[...] Is it going to affect a lot of people, how many people will read a story about heart disease and how many people will read a story about Down syndrome? Most will read about heart disease, so heart disease will be published. That's how it works" (Journalist).

Other valuations perceived by the actors were "novelties" and "scientific and technological innovations" in the health and diseases area. This perception corroborates the analysis of Carlini (2012), who shows that "new" diseases such as the H1N1 flu are more frequent in newspapers, in addition to recent research detecting these viruses and studies on the effectiveness of vaccines.

In addition, both journalists and health managers observed that health has been presented in the media in terms of aesthetics, quality of life, and well-being. However, it is interesting to note that one of the journalists interviewed feels uncomfortable in excessively contributing to the quest for aesthetics whereas another emphasises the importance of this approach, given that it is a subject of public interest ${ }^{2}$ :

“[...] Sometimes I feel like I'm contributing to the crazy quest for looks” (Journalist).

Studies on the media dissemination of issues related to oral health reveal that newspapers have a strong aesthetic appeal focused on market-oriented health practices (Cavaca, Gentilli, Zandonade, Cortellete Junior, Emmerich, 2012) in which "body aesthetics seem to rely on an array of consumption that presides over journalistic guidelines" (Oliveira, 2013, p. 9).

In terms of quality of life and well-being, the constitutive role of the media and of Information and Communication Technologies (ICTs) in the aesthetic approach is intrinsic in the production of risk, given that they not only contribute to the expansion of risks but also often accelerate and emphasise them in their mediatic discourses (Van Loon, 2003).

"There is another side that I don't really like to do, but that is a part of it: the newspaper is a trade, you know, the goal is to sell. And often the news that do sell are not the issues that I consider to be of greatest service to the population.” (Journalist).

${ }^{2}$ The public interest, as mentioned in this article, refers to the notion of the public space (PS) from Romeyer (2010). According to this author, PS refers to a process that only exists due to 2 essential elements: the dissemination of information and the discussion/debate on this information. Therefore, the mass media has the power to activate the PS, and the freedom of information extends it.

The diffusion and assimilation of scientific knowledge can lead to the reproduction of ideology and cultural beliefs in 
everyday life, influencing behaviours and policies (O'Connor \& Jeffe, 2013). In the field of Public Health, the diffusion of risk factors through the "scientific journalism" of the mass media causes many patients/individuals to adopt preventionist attitudes, such as the use of vitamin supplements that were not necessarily a medical instruction but that are taken based on knowledge emphasised by the media discourse (Castiel \& Vasconcellos-Silva, 2006). In addition, sometimes the media discourse focuses on the blaming of individuals in its rhetoric relating to diseases/afflictions, disregarding the social, political, and economic context in which these individuals are inserted (O'Connor \& Jeffe, 2013). In relation to children's brain development, for example, the British press has emphasised normative judgements about the responsibility of parents and the influence of the emotional quality between parents and children in infant neuro-development, disregarding the contributions of broader political and social initiatives (O'Connor \& Jeffe, 2013).

Castiel (2003) emphasises the importance of studies that have the goal of understanding how journalists participate in the symbolic construction of health news, given that the lack of training of these actors can have important implications and even lead to disinformation. In this sense, the daily serving of news about new treatments, tests, products, and procedures can have a harmful impact on health care consumers (Schwitzer, 2008).

The answer of one of the journalists reveals that some diseases tend to be neglected by newspapers, possibly because the journalists do not know they exist:

“[...] but I don’t know everything. The less known (diseases), I probably don't know, even with my experience, so we're stuck in the cycle of always talking about the same ones” (Journalist).

This ignorance on the part of journalists in relation to some diseases has been observed in other studies that aim to assess the content of the health news disseminated by journalists (Schwitzer, 2008). These studies also indicate that the time that these professionals have to search for stories, the space available for publication, and the training of journalists are some of the obstacles of the problems identified (Schwitzer, 2008).

\subsection{Health News Demand}

In Public Health, health demands arise from interactions between users, professionals, and managers in relation to the offer of health services. In this sense, health problems are understood as demands expressed by users. In addition, demands tend to reduce the individual to the disease, sometimes disregarding the context in which they are inserted (Pinheiro, Guizardi, Machado, Gomes, 2005). According to this logic, we understand that health news demand comprises the interaction between users of the SUS, journalists, press officers, and health managers, among others. These actors sometimes influence or determine which health topics will be publicised by newspapers.

This determination goes beyond the attributes of the news, involving the relationship between journalists and ASSCOM and between journalists and their sources (Martinuzzo, 2013).

In essence, communication advisories act in the dissemination of topics to the press and the public and function as a bridge between journalists and their sources. They work under the same paradigm of the newspaper newsrooms and thus are also guided by news values (Martinuzzo, 2013).

The goal of the sources and of the journalists, when a press office acts as an intermediary, should be the publication of news of public interest. Therefore, this dialogue can have a bi-directional flow: journalists in newsrooms may submit to the press office the demands to be taken to the advised sources, and the press office can offer suggestions based on the interests of those whom they advise (Martinuzzo, 2013).

This bidirectional flow can be traced in the answers of the actors:

"We often guide the press through our site. We have this proactive position of guiding the press through the information of what gets done, which sometimes is not seen" (Press Advisor). (Journalist).

"So, every day they send us epidemiological data [...] every Wednesday we published the week's data"

These answers support Martinuzzo's (2013) assertion that communication advisories must have two major objectives: suggesting guidelines for the press and meeting the demands of journalists.

Health news demand also permeates the public agenda, i.e., the news that the reader identified with and whose subject has been under debate in society. Romeyer (2010) calls this subject public labelling, in which everything that the media disseminates becomes an object of public attention. For this visibility to exist, a group of individuals must be interested in the topic and consider it as being of public interest. In this sense, a socialisation of health discourse is promoted by the media (Romeyer, 2010) insofar as journalists seek "health stories", also called "life stories", to gain readers' attention (Carlini, 2012).

"And there's a section that attracts lots of readers, the life stories. Stories with emotion, people who overcame 
illnesses, people who overcame serious illnesses” (Journalist).

This multiplication of forms of expression leads to a diversification of the actors who have been given the right to speak in regard to health news (Hilton, Wood, Patterson, Katikireddi, 2014), including the sick (Romeyer, 2010). The use of "personalised stories" has been one of the resources used by journalists to gain the attention of their audience on the subject of health/disease, even if they have not received any specific preparation to do so (Friedman, Tanner, Rose, 2014).

It is important to note that these health stories focus on medical topics involving lifestyles and individual responsibility, with limited socio-political concerns for health (Hodgetts, Chamberlain, Scammell, Karapu, \& Nikora, 2008).

Nevertheless, the journalists also made reference to the importance of health news as a service to society:

"And then the criteria for us to choose the news vary widely. One of them is the services. What are they? Vaccination campaigns, free tests, [...], where one should go, where to search, what to do" (Journalist).

Another aspect of health news demand concerns the manner in which health services are portrayed by the printed media in the framework of a hegemonic hospital-centric health care model focused on the disease, the cure, and the medicalisation of life and thus centred on hospitals (Menegon, 2008).

In this sense, this study has shown that both ASSCOM and SESA managers agreed that the Brazilian health system should be better known by journalists to prevent the publication of misconceptions:

"Nobody wants to know that the patient is there (in the hospital) and that sometimes he might even be in the hallway, but he's being supervised all the time. He's being evaluated, medicated, is undergoing tests [...] So these things are never shown the way they really are, no matter how much we explain it” (ASSCOM).

Understanding the functioning of the Brazilian health system and its policies is crucial because journalists are opinion makers, lending legitimacy to facts, and their power lies in how they report events (Martinuzzo, 2013). Therefore, the ignorance on the part of these professionals in relation to health policies becomes a large gap (Ortona \& Fortes, 2012).

\subsection{Everyday Difficulties of Health Journalism}

The respondents' opinions revealed the existence of two filters: the ASSCOM and editorial meetings. The first is used by the SESA in its relationship with the media, whereas the second is present in newsrooms.

A press advisor should act as a facilitator, intermediary, and mediator in the journalist's relationships with the institution and the sources (Duarte, 2003). This work includes: producing material for the media, suggesting the agenda, indicating sources to facilitate the work of journalists, and preparing manuals on how potential sources should act in relation to the media (Martinuzzo, 2013).

In addition, "the press office must be available at all times to meet the demands of journalists" (Martinuzzo, 2013, p. 75); it must know how to "sell" the agenda and update the institution's website with reliable and useful links (Duarte, 2003).

"Yes, we update the site daily, forward the press release, we even get to call them. We call it 'selling the agenda", (Press Advisor).

Nevertheless, the press advisor must have a proactive stance to contribute to the organisational identity and the image of the institution for which he or she works. The press advisor must also participate and be heard in the internal decisions of the entity that he or she represents (Martinuzzo, 2013). In the context of the SESA, the reports presented in this study suggest that the advisors must participate in seminars and discussions on the health situation of their state so that they can better dialogue with the media.

“[...] if they asked for epidemiological data on AIDS, we're going to get these data and send what they asked for. Why? If we send all the data, they won't understand it, and then they will be calling us all day” (Press Advisor).

The SESA management itself admits that as managers, they could also take a more proactive stance and bring the issues that are important to Public Health to the ASSCOM and, consequently, to the media:

“[...] there is an issue that is our responsibility: we don't know how to disseminate, we don't have the profile of those who can make the communication flow better. I think we also have some difficulty in giving more visibility to the information we have" (Manager).

Furthermore, journalists emphasise that most of the time, they are the people who go to ASSCOM with regard to some demand and that the opposite flow rarely occurs:

"Yes, they send us some topic suggestions, but it is rarer because the things that interest us they won't suggest, right?” (Journalist). 
This phenomenon can occur for several reasons: fear of the alarmist and sensationalist tone occasionally used by the media (Vaz, Pombo, Fantinato, Pecly, 2007; Ransohoff \& Ransohoff, 2001) and the fact that journalists tend to prioritise negative news (Traquina, 2013) and denigrate the image of the SESA. Therefore, some health topics can be silenced by the Department, as reported by a manager when she was asked if she knew something that was important to the state that has not been reported in the newspapers:

"We have been finding many cases of trachoma, but we still have not sent it to the press" (Manager).

"[...] I also see that we do not care to talk. Just so that there is no alarm, so as not to generate panic, when the issue is under control" (Manager).

By contrast, editorial meetings act as a gatekeeper, i.e., a first gate through which the news must go and in which the topics are decided upon. In this case, the editors decide what news will or will not be publicised. These decisions are highly subjective, arbitrary, and dependent on a value judgement influenced by the intentions of those responsible for the gatekeepers (Traquina, 2004). The editorial meetings are the starting point for defining the perspectives of the newscast, the paper's editorial demands, the routine of the journalists, and the spaces available for the topics (Fortes, 2008; Duarte, 2003). Thus, between the topics suggested by reporters (or journalists) and the viability of the news piece, there is a vacuum that may or may not be filled, in accordance with what is set at these meetings:

“So, it often happens that we make a suggestion and it is not accepted, it doesn't become an article because it is a subject that the newspaper doesn't consider quantitative enough to reach a large audience, a large mass” (Journalist).

However, this selection of news is not the only interface of the news production process; there are other aspects in the bureaucratic organisation of editorial rooms (Traquina, 2004), such as the journalists' relationship with their sources of information.

The main sources of health journalism include the following: experts; validated scientific publications; press releases (notices on topics sent by the communication advisory agencies to newsrooms); businesses, NGOs, and other interest groups; conferences or scientific meetings; journalistic material (current or archived); patients and their family members; users; consumers; celebrities; and, of course, the internet (Tabakman, 2013). According to Romeyer (2014), these sources can also be called alert launchers.

Journalists consider that this relationship might be one of the greatest challenges of their work routine because the public relations teams of healthcare institutions strive to promote their own interests (Hodgetts, Chamberlain, Scammell, Karapu, Nikora, 2008). The journalists emphasise that they are aware of these interests and that they are dependent on their sources (Hodgetts, Chamberlain, Scammell, Karapu, Nikora, 2008).):

“[...] I do not write anything, I write what others said, what others explained. I depend on them” (Journalist).

The difficulties in the relationship with sources are varied; sources often do not understand the journalistic routine and the necessity of short deadlines (Friedman, Tanner, Rose, 2014), in addition to the importance of cultivating sources who are available, reliable, and loyal (Hodgetts, Chamberlain, Scammell, Karapu, Nikora, 2008).

In the perception of some journalists, government officials and health professionals are the most available sources (Hodgetts, Chamberlain, Scammell, Karapu, Nikora, 2008).), which is contrary to what other journalists observe:

“[...] there are professionals who do not understand how the newspaper works: they don't talk on the phone, they only speak personally. We don't get in touch with these professionals again. Some doctors want to read the article before publication. If they have a series of requirements, they won't be regular sources for the newspaper” (Journalist).

Sources need to understand the editing process: what was said by the source will be reframed by the journalist (Martinuzzo, 2013). This editing aims to transform the specialised language of scientific discourse into a language that is accessible to the lay public (Cunha, 2008).

During the process of reformulating the discourse, the topic is framed in the typical structure of a news piece, often following the editorial guidelines of the media vehicle, with the use of phraseological resources, such as omission, substitution, or reference, followed by an explanation of technical terms in accordance with the public for whom the publication is addressed (Cunha, 2008). Nevertheless, misconceptions and distortions are unacceptable (Martinuzzo, 2013).

The managers themselves perceive, understand, and recognise the need for translating, although they seem uncomfortable with this decoding:

"[...] when we talk to a reporter, it seems that everything has to be translated, and there is a certain difficulty in translating that into a more commercial language, more accessible to the general public" (Manager).

By contrast, journalists highlight the importance of translating these medical terms, which were called "doctorese” by 
one of the respondents:

"Some doctors are very sensitive about the technical term. There are professionals who are resistant to making any translation of this doctorese" (Journalist).

This difficulty may be due to the distortions that may occur during the process of editing an interview to be published (Cunha, 2008; Duarte, 2003) or due to the conflicting and negative tone of the news (Duarte, 2003), as a manager notes:

"Sometimes, what I read in the paper is not a faithful portrayal of what I said. Something is distorted [...]" (Manager).

Health managers indicate that the abilities to communicate well and transfer information and health data are important requirements in their profession (Rodriguez, Bereguera, Pujol-Ribera, Capella, Luiz de Peray, Roma, 2013), but they recognise the difficulty of playing this role:

"So, we end up talking more to our own public, as if the information just circulated in this environment. And when we need to send this information out, it is difficult for us, even in terms of speaking” (Manager).

It is possible that this difficulty contributes to the omission of health topics that are relevant to minorities and disadvantaged groups, reflecting the ignorance of these topics among journalists (Hodgetts, Chamberlain, Scammell, Karapu, Nikora, 2008). Scientific knowledge and production may be trapped among researchers, without surmounting the walls of universities. This situation raises opportunities for health researchers to engage with journalists to rethink and promote a more civic-oriented health journalism (Hodgetts, Chamberlain, Scammell, Karapu, Nikora, 2008). The need for this dialogue between scientists and journalists is urgent and much needed in the current mediatised context. Due attention can contribute to keeping the public informed about health issues that are being discussed in the scientific world (Ransohoff \& Ransohoff, 2001).

The issue of the race against time reflects another particularity of health news that was noted by respondents: newspapers tend to always report on the same topics and the same diseases because they are the more readily apparent phenomena, because of the short amount of time for seeking other important topics, or because some topics do not make it onto the agenda of newsrooms (Hodgetts, Chamberlain, Scammell, Karapu, Nikora, 2008):

“[...] what happens in the newspaper: the daily paper has a hard time thinking about things. We end up reporting whatever shows up in our face" (Journalist).

Corroborating these findings, studies on the media content of health news in the United States have revealed that journalists normally cannot discuss in depth the health issues addressed (Schwitzer, 2008) and thus more solid approaches to health are non-existent.

\subsection{Limitations of the Study}

Despite the wealth of details obtained with the reports presented, this study interviewed a limited number of individuals. Because the approach is qualitative, these results cannot be generalised to other populations because the findings may not represent the opinions of actors in different institutions and realities. However, the study reveals certain representations that might be common to the actors involved in the communicational process of Brazilian media.

\section{Conclusions}

It was observed in this study that harmony between the actors is rarely observed. This dysfunctional relationship can lead to a decrease in the quality of health news.

It is suggested that newsrooms journalists receive better training to act more appropriately in the dissemination of information relevant to health and to the SUS. Similarly, health managers must be better prepared to address the media, decrease the use of technical terms, and attempt to understand the particularities of the work routine of newsrooms.

In this sense, manuals for more effective communication with the media can be adopted or prepared by the ASSCOM for use by health professionals and managers. Given that the ASSCOM is a bridge between journalists and their sources, it should have a more engaged and proactive attitude. It should better guide the press, finding resources to attract media attention to the health topics that it considers relevant for the population.

The representation of the opinions of the actors indicated negligence/difficulty in disseminating some health topics that do not affect a sufficient number of people to be covered by the newspapers.

Finally, a combination of forces that challenge the power of the sources of information, in the sense of disseminating and influencing the news content, was observed. The superiority of journalists in editing and determining the selection and framing of health topics was also observed. 


\section{Acknowledgements}

This study is the result of a Master's thesis presented in the Post-Graduate Program in Collective Health and funded by FAPES/CNPq/MS-Decit/SESA.

\section{References}

André, A. M., \& Ciampone, M. H. T. (2007). Competencies to manage basic healthcare units: manager's perception. Rev Esc Enferm, 41, 835-840.

Araújo, I. S., \& Cardoso, J. M. (2007). Communication and Health. Rio de Janeiro: Editora FIOCRUZ, 152.

Bardin, L. (2011). Content analysis. $3^{\mathrm{a}}$ ed. São Paulo: Edições 70, 279.

Barlett, C., Sterne, J., \& Egger, M. (2002). What is newsworthy? Longitudinal study of the reporting of medical research in two British newspapers. Br. Med. J. Londres, 325, 81-84. https://doi.org/10.1136/bmj.325.7355.81

Brazil. (2004). Supplementary Law No. 317 of December 30, 2004. Organizes the functioning of the State Health System of the State of Espírito Santo - SES / ES, changes the organizational structure of the State Health Department - SESA and the State Institute of Public Health - IESP, and other provides.

Caldas, G. (2003). Relacionamento Assessor de Imprensa/Jornalista: SomostodosJornalistas! In: DUARTE, J. (Org.) Assessoria de Imprensa e relacionamento com a mídia: teoria e técnica. Atlas: São Paulo, 306-313.

Carlini, M. (2012). Reporting on health-related research in two prestigious Brazilian newspaper. Revista do EDICC, 1, 314-320.

Castiel, L. D. (2003). Insecurity, ethics and communication in public health. Rev. Saúdepública, São Paulo, 37(2), 161-167. https://doi.org/10.1590/S0034-89102003000200001

Castiel, L. D., \& Vasconcellos-Silva, P. R. (2006). Precariousness of excess: information and communication in Public Health. Rio de Janeiro: Editora Fiocruz, 168.

Cavaca A. G., \& Vasconcellos-Silva, P. R. (2015). Diseases neglected by the media: a theoretical approach. Interface comun.saúde educ., 19(52), 83-94. https://doi.org/10.1590/1807-57622014.0205

Cavaca, A. G., Emerich, T. B., Vasconcellos-Silva, P. R., Dos Santos-Neto, E. T., \& Oliveira, A. E. (2016). Diseases Neglected by the Media in Espírito Santo, Brazil in 2011-2012. PLOS Neglected Tropical Diseases, 1-19.https://doi.org/10.1371/journal.pntd.0004662

Cavaca, A. G., Gentilli, V., Zandonade, E., Cortellete Junior, M., \& Emmerich, A. (2012). Oral health in the printed media: analysis of newspaper articles in the years 2004-2009. Ciênc.saúdecoletiva., 17(5), 1333-1345. https://doi.org/10.1590/S1413-81232012000500027

Collins, P. A., Abelson, J., Pyman, H., \& Lavis, J. N. (2006). Are we expecting too much from print media? Na analysis os newspaper coverage of the 2002 Canadian helathcare reform debate.Soc. sci. med., New York, 63, 89-102. https://doi.org/10.1016/j.socscimed.2005.12.012

Cunha, R. B. (2008). From scientific to journalistic: comparative analysis of health-related discourse. Interface comun. saúde educ., 12(24), 195-203. https://doi.org/10.1590/S1414-32832008000100015

Duarte, J. (2003). Press relations and media relations: theory and technique. São Paulo: Atlas, 411.

Fausto, N. A. (2012). Mediatisation of Lula's disease: meanings in circulation around a signifying body. In: JANOTTI JUNIOR, J.; MATTOS, A. M.; JACKS, N. (org.). Mediation and Mediatisation. Salvador: EDUFBA; Brasília: Compós, 297-321.

Fortes, L. (2008). The secrets of essays: what journalists only discover on daily routine. São Paulo: Contexto, 112.

Friedman, D. B., Tanner, A., \& Rose, I. D. (2014). Health Journalists' Perceptions of Their Communities and Implications for the Delivery of Health Information in the News. J. Community Health., 39, 378-385. https://doi.org/10.1007/s10900-013-9774-x

Gibbs, G. (2009). Analysing Qualitative Data. SAGE Publications of London, New Delhi and Singapore, 176. http://dx.doi.org/10.4135/9781446282243

Herzlich, C., \& Pierret, J. (2005). A disease within a public space: AIDS in six french newspapers. Physis: revista de saudecoletiva, 15(supl.), 71-101. http://dx.doi.org/10.1590/S0103-73312005000300005.

Hilton, S., Wood, K., Patterson, C., \& Katikireddi, S. V. (2014). Implications for alcohol minimum unit pricing advocacy: What can we learn for public health from UK newsprint coverage of key claim-makers in the policy debate? Soc. sci. med., 102, 157-164. https://doi.org/10.1016/j.socscimed.2013.11.041 
Hodgetts, D., Chamberlain, K., Scammell, M., Karapu, R., \& Nikora, L. W. (2008). Constructing health news: possibilities for a civic-oriented journalism.Health, 12(1), 43-66. https://doi.org/10.1177/1363459307083697

Jornal, A. G. (2015). Histórico. Disponívelem: http://gazetaonline.globo.com/index.php?id=/redegazeta/historico/index.php.>. Acessoem: 01 fev. 2015.

Jornal, A. T. (2015). Historic. Available in: <http://www.redetribuna.com.br/jornal/historico>. Acessoem: 14 jan. 2015.

Marinho, S., Ruão, T., Lopes, F., Pinto-Coelho, Z., \& Fernandes, L. (eds.). (2012). Crossed views on Communication in Health: report of a debate. Braga, University of Minho. Available in: <www.lasics.uminho.pt/diseaseinthenews/?>. Acessoem 20 jan. 2015.

Martinuzzo, J. (2013). Six fundamental questions of strategic strategic press. Rio de Janeiro: Mauad X, 132.

Menegon, V. S. M. (2008). The news about the health service crisis in the newspaper.Psicol.soc., 20, edição especial, 32-40.http://dx.doi.org/10.1590/S0102-71822008000400006

Minayo, M. C. S. (2010). The challenge of knowledge: methodology of (qualitative) social research on health. 12. ed. São Paulo: Hucitec, 407.

Moscovici, S. (2009). Social Representations: Investigations in Social Psychology. Translate. Pedrinho A. Guareschi. 6. ed. Petrópolis: Vozes, 404.

O’Connor, C., \& Joffe, H. (2013). Media representations of early human development: Protecting, feeding and loving the developing brain. Soc. Sci. Med., 97, 297-306. https://doi.org/10.1016/j.socscimed.2012.09.048

Oliveira, V. C. (2000). Media communication and the Single Healthcare System. Interface - Comunic, Saúde, Educ, Botucatu, 4(7), 71-80. http://dx.doi.org/10.1590/S1414-32832000000200006

Oliveira, V. C. (2013). The senses of the health of print media.RECIIS - R. Eletr. De Com. Inf. Inov. Saúde, 6(4), supl.,fev. http://dx.doi.org/10.3395/reciis.v6i4.622.

Ortona, C., \& Fortes, C. A. P. (2012).Do journalists who write about health know what it means 'Humanization of Health Care'?Saúde Soc., 21(4), 909-915. http://dx.doi.org/10.1590/S0104-12902012000400010

Pinheiro, R., Guizardi, F. L., Machado, F. R. S., \& Gomes, R. S. (2005). Demand for Health and the Right to Health: Freedom or Necessity? Some considerations on the constituents of practices and completeness. In: Pinheiro, R., Araujo de Mattos, R. (Org.). Social construction of the demand: right to health, workmanship, participation and public spaces. Rio de Janeiro: CEPESC/UERJ: ABRASCO, 11-32.

Ransohoff, D. F., \& Ransohoff, R. M. (2001). Sensationalism in the Media: When Scientists and Journalists May Be Complicit Collaborators. Effclin. Pract., 4, 185-188.

Rodriguez, D., Berenguera, A., Pujol-Ribera, E., Capella, J., Luiz de Peray, J., \& Roma, J. (2013). Identification of current and future competencies of public health professionals. Gacsanit, Barcelona, 27(5), 388-397. https://doi.org/10.1016/j.gaceta.2012.10.005

Romeyer, H. (dir.). (2010). La santé dansl'espace public. Rennes: Ed. Presses de l'EHESP, Collection Comunication, Santé, Social, 216. http://edc.revues.org/2648

Romeyer, H. (2014). Health, risk and media. In : Discipline: Health, risk and media., 2014, Rio de Janeiro, BR. Postgraduate Program in Information and Communication in Health of the Institute of Communication and Scientific and Technological Information in Health of the Oswaldo Cruz Foundation.

Schwitzer, G. (2008). How do US journalists cover treatments, tests, products, and procedures? An evaluation of 500 stories.PLos med., 4(5), 700-704. https://doi.org/10.1371/journal.pmed.0050095

Silva, G. (2014). To think about newsworthiness criteria. In: Silva, G., Silva, M. P., Fernandes, M. L. (Orgs.) Noticiability Criteria - conceptual issues and applications Florianópolis: Insular, 51-70.

Spink, M. J. (1993). The concept of social representations in social psychology. Cad. Saúdepúbl., 9(3), 300-308. http://dx.doi.org/10.1590/S0102-311X1993000300017

Tabakman, R. (2013). The health on the media: medicine for journalists, journalism for physicians. São Paulo: Summus Editorial, 211.

Tong, A., Sainsbury, P., \& Craig, J. (2007). Consolidated criteria for reporting qualitative research (COREQ): a 32-item checklist for interviews and focus groups. Int. J. Qual. Health Care, 19(6), 349-357. http://dx.doi.org/10.1093/intqhe/mzm042

Traquina, N. (2004). Theories of Journalism I: because news is as it is. Florianópolis: Insular, 224. 
Traquina, N. (2013). Theories of journalism II: the journalistic tribe - a transnational interpretive community. Florianópolis: Insular, 208.

Van Loon, J. (2003). Risk and Technological Culture: Towards a sociology of virulence. London: Taylor \& Francis e-Library, 245.

Vaz, P., Pombo, M., Fantinato, M., \& Pecly, G. (2007). Risk factors in the media. Interface - Comunic, Saúde, Educ, 11(21), 145-163. http://dx.doi.org/10.1590/S1414-32832007000100013

\section{Notes}

Note 1. This study is the result of a Master's thesis presented in the Post-Graduate Program in Collective Health and funded by FAPES/CNPq/MS-Decit/SESA-BRAZIL.

\section{Appendix A. Frame 1}

Frame 1. Explanation of the dimensions after interview fragments were categorised. Espírito Santo, 2014

\begin{tabular}{cc}
\hline Dimension & Explanation \\
\hline $\begin{array}{c}\text { Media valuations (the negative, the quantitative, the novelties } \\
\text { and the aesthetics) } \\
\text { Health news demands }\end{array}$ & $\begin{array}{c}\text { What is reported and emphasised about health in the state } \\
\text { newspapers - possible neglected health themes } \\
\text { Where they come from and how to hunt for health news } \\
\text { Difficulties of the actors' work routine and how they influence } \\
\text { the health news }\end{array}$ \\
\hline
\end{tabular}




\section{Appendix B. Figure 1}

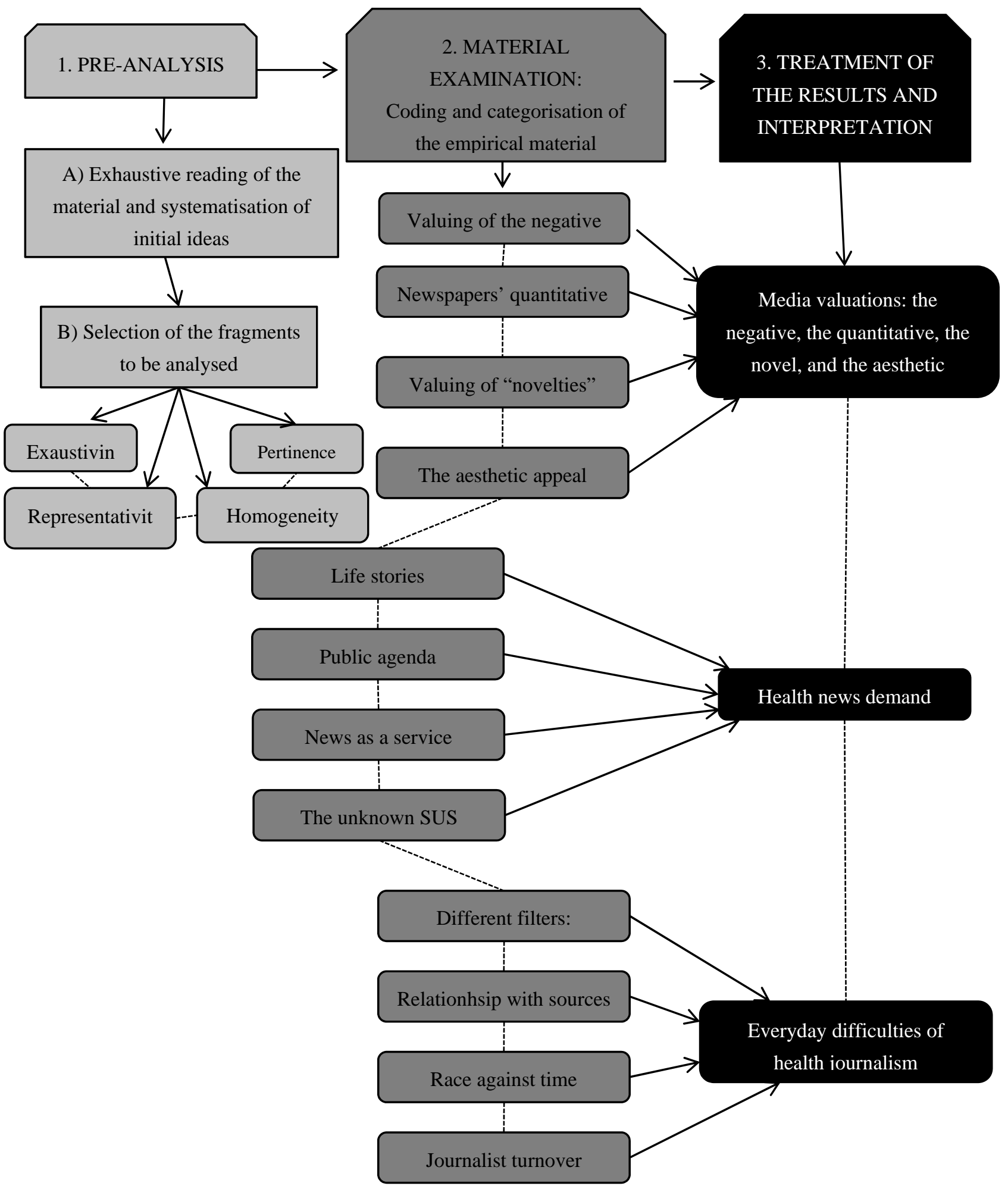

Figure 1. Description of the process of categorisation of interviews. Espírito Santo, 2014

\section{Copyrights}

Copyright for this article is retained by the author(s), with first publication rights granted to the journal.

This is an open-access article distributed under the terms and conditions of the Creative Commons Attribution license which permits unrestricted use, distribution, and reproduction in any medium, provided the original work is properly cited. 